\title{
CHEAP SYARIAH QURBAN INVESTMENT (CSQI) PROGRAM: DETERMINING FACTORS OF POTENTIAL PARTICIPANTS DECI- SION MAKING
}

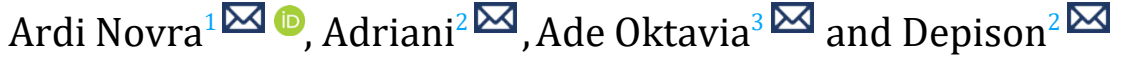 \\ ${ }^{1}$ CoE-HE SIFAS (Sustainable Integrated Farming System), University of Jambi, Indonesia \\ ${ }^{2}$ Faculty of Animal Science, University of Jambi, Indonesia \\ ${ }^{3}$ Faculty of Economic and Business, University of Jambi, Indonesia
}
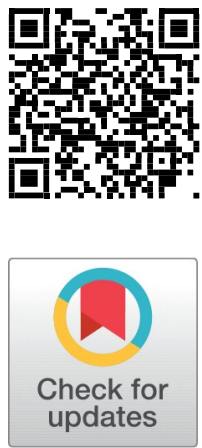

Received 15 March 2021

Accepted 30 March 2021

Published 30 April 2021

DOI 10.29121/

granthaalayah.v9.i4.2021.3806

Funding: This research received no specific grant from any funding agency in the public, commercial, or not-for-profit sectors.

Copyright: (C) 2021 The

Author(s). This is an open access article distributed under the terms of the Creative Commons Attribution License, which permits unrestricted use, distribution, and reproduction in any medium, provided the original author and source are credited.

\section{ABSTRACT}

The evaluation of community service activities (CSA) for the regional superior product development program (RSDP) is to analyze qurban behavior and the determining factors that influence program decisions. A survey of 87 participants in the CSQI program surgery was conducted online from several groups, both experienced and inexperienced as committee members and qurban worship participants. The results of the evaluation of potential candidates for qurban participants show that generally the sources of information coming from academics, practitioners and the bureaucracy are interested (56.17\%) to participate in the CSQM program, while the parties have not decided (42.52\%) and are not interested at all $(2,29 \%)$. A person's experience both in participating in the management of qurban activities and as a participant does not significantly influence their decision to join the CSQI program. The decision to participate in the CSQI program is determined by the payment system, the information they receive and the level of their readiness to face qurban activities in the next period. Based on the results of the evaluation, it can be concluded that the promotion and marketing policies of the CSQI program need to be improved or modified in order to provide clear information and provide an alternative arisan (installment) repayment system and so that the effectiveness is focused on the target market segment in the form of religious-related qurban management institutions, offices and neighborhood association.

Keywords: Csqi, Participants, Qurban, Socialization, Advertising

\section{INTRODUCTION}

Indonesia's domestic beef production, which is estimated to be around 403,668 , has not been able to meet domestic demand which reached 663,290 tons or local breeders are only able to meet domestic needs of around 60.9\% Reily (2018). Based on 
data from the Central Statistics Agency (BPS), the supply of domestic beef and beef cattle is currently around $98 \%$ still coming from smallholder farms with \pm 4.2 million household workers. The supply chain channel for livestock and beef commodities is very diverse and quite long involving quite a number of business actors (7-9 business actors), where the business actors play the most role being cutters (butchers), interregional traders (suppliers), and inter-village (small collectors) Saptana and Ilham (2017). Beef supply basically comes from the results of beef slaughter with the supply component consisting of beef production from slaughterhouses or animal slaughterhouses, beef intake, stock and beef production Firman et al. (2018). Supply is the sum of production, production stock, the number of imported goods, and the output of goods Ilham (2001); Kariasa (2012). Furthermore, the average monthly demand for beef reaches 55 thousand tons, while according to the Director General of Animal Husbandry and Animal Health, the demand for beef ahead of Eid is estimated at 119 thousand tons Reily (2018).

One of the obstacles in accelerating the development of smallholder beef cattle is the low access of farmers to capital resources (financing), including in the fattening business. The source of capital for beef cattle business in rural Indonesia generally comes from own capital, the results of complaints between individuals and government or private assistance programs Widiati (2012). The components of the agricultural sector, which consist of the food crops, the plantation, the livestock, and the fisheries sub-sector, are less attractive to banks in financing because they have risks, one of which is the risk of falling prices Saptana and Ilham (2017). Sharia financing schemes, namely salam, istisna, ijarah, ijarah mum tahiyah bit tamlik, musyarakah, mudharabah as alternatives to farmer financing, this scheme has a great opportunity to be implemented because it has agricultural-based characteristics with no interest, partnerships with profit loss sharing, and fulfillment of goods suitable for farmers Ashari (2005). (Ashari and Saptana, 2015). Mudaraba is a business collaboration between two parties, where the first party or Shahibul Mall provides $100 \%$ of the capital while the other party manages it research results show that mudharabah financing has a negative and significant effect on the ROE (return on equity) level, while musyarakah financing has a positive and significant effect Permata (2014).

Islamic funds significantly outperformed conventional funds in the riskiest asset class, equity, one year before and during the global financial crisis Boo et al. (2017). The studt results showed in 2014 and 2016 Islamic mutual fund performance be superior to Indonesia than Malaysia but while in 2015 Islamic mutual fund performance Malaysia be superior compared to Indonesia Basuki and Khoiruddin (2018). While Islamic funds from these markets are competitive to international equity benchmarks, funds from especially Western nations with less Islamic assets tend to significantly underperform Hoepner et al. (2011). Islamic finance has the potential for further contributions in at least three dimensions, namely a) it promises to foster greater financial inclusion, especially of large underserved Muslim populations b). its emphasis on asset-backed financing and risk-sharing feature means that it 
could provide support for small and medium-sized enterprises (SME), as well as investment in public infrastructure, and c) its risk-sharing features and prohibition of speculation suggest that Islamic finance may, in principle, pose less systemic risk than conventional finance Kammer et al. (2015).

The Cheap Qurban Sharia Investment Program (CQSI) is an alternative in maintaining market balance by taking into account the needs of consumers (Qurban participants) and producers (cattle breeders). The CSQI program can be used as an instrument in maintaining the stabilization of beef cattle commodity prices, minimizing price play by intermediary traders, increasing the certainty of smallholder livestock businesses, reducing the tendency of increasing commodity prices continuously so that the domestic and world price gap widens and prevents the practice corrupt practices in hunting for import quota permits due to the difference between imported and domestic meat prices. In the CSQI program Novra (2020), Qurban participants will save $19.79 \%$, the ummat funds can be used to empower breeders, and open new business opportunities for certain individuals Novra et al. (2020). The development of the concept of Islamic finance in society is in line with the emergence of various studies related to financial concepts based on the principle of justice where there is a division not only in terms of profits but also in losses which are usually called profit-loss sharing Murniati (2018).

Comparison between the concept of interest and profit-loss sharing which is built based on the concept of Islamic finance according to stated that profit-loss sharing is the only concept that provides justice for all parties Sugema et al. (2010). The weaknesses and strengths of the concept of profit-loss sharing which are evaluated theoretically by looking for reasons for failure to implement this concept occur in the process of implementation, in other words the organizer is the only one responsible for this failure so it is necessary to separate the organizing agency so that it is more focused in order to guarantee. the implementation of the concept of justice AbdulRahman et al. (2014). Islamic finance is built on the basis of the Islamic religious philosophy with the principle of justice so that in the practice of sharia economicbased finance, it must be far from the element of usury Sugema et al. (2010). Riba is the excess that is collected along with the amount of debt that contains elements of persecution and oppression, not just excess or additional money Codification of Bank Indonesia regulations - liabilities and capital for the implementation of sharia principles in the activities of raising and channeling funds as well as sharia services, sharia bank products and sharia business units (2012). Riba is known as a term that is closely related to economic activity and its prohibition is one of the main pillars of Islamic economics, in addition to the implementation of zakat and the prohibition of maisir, gharar and other things that are vanity. The calculation mechanism for the ideal profit sharing according to Islamic economics consists of 2 (two) types, namely profit sharing in which the total business income is reduced by operating costs to get profit, aka net profit, and revenue sharing, which is profit based on total business income before deducting costs. operational alias gross income. 
Individuals in society naturally tend to choose collective action when there are similarities in terms of goals to be achieved and when they feel uncertainty and the risks they face if they move alone Syamsuddin et al. (2007) Empowerment of ummah funds is a shared responsibility and goal so that the existing potential can be optimized for the welfare of the community. For this reason, the implementation of low-cost programs should be carried out institutionally with a collective action approach. Various studies show that the role of collective action can increase people's access to institutions when they demand public services Mahmud (2002) and are needed in coordinating individual activities, compiling group rules and mobilizing resources in the form of funds, manpower and other materials Meinzen-Dick and Knox (1999) The implementation of the low-cost qurban model as one of the ways to utilize ummat funds for community empowerment can be done through partnerships. Partnerships can be carried out directly between smallholder breeders and owners of qurban funds, but it will be more effective if coordinated or facilitated by a special institution, both purely business and social institutions.

CSQI is a form of new investment based on partnerships between fattening cattle breeder households, investment intermediary institutions and participants or practitioners of qurban worship (consumers). The introduction of the CSQI program to potential consumers through the promotion and marketing of CSQI services still has many obstacles so that a special strategy is needed, including the segmentation of the target market and consumers. Various decisions to be made by investors based on the prevailing factors and the eventual outcomes for each decision and would identify the most influencing factors on the company's investors' behavior on how their future policies and strategies will be affected since investment decisions by the investors will determine the company's strategy to be applied Jagongo and Mutswenje (2014). Overall, the findings contribute to the understanding of how investment-based crowdfunding can be a viable source of entrepreneurial finance and how entrepreneurs' campaign decisions affect investor participation in this new form of entrepreneurial finance Hervé etal. (2019). Investment policy makers should be careful to put financial advice forward as a mechanism to curb the ill effects of low financial literacy and that steering people towards more accurate self-assessments seems a more promising route Kammer et al. (2015). The attitude, subjective norm, perception of behavior control, subjective norm, over confidence, excessive optimism, herd behavior has positive effect on investors' intention in investing, and there is no influence between psychology of risk to investor attitude in investing Pahlevi and Oktaviani (2018).

Investors need information which are important factors as a basis for determining investment choices Halim (2005). The intentions of individual investors are reflected in the estimation of stock returns that are calculated using various information to behave that grows because of information that provokes a person's motivation to take a decision Prawirasasra (2016). News, information, politics, risk, security, policy, rumors, external factors (global markets), and consideration of mar- 
ket participants beliefs in making intentions to invest in shares Lubis et al. (2013). Some research results show rationally that individual investors are more profitable in investing, it makes sense to assume that if individual investors prefer these investments, they are more motivated to take actions that benefit than less profitable investments Cuong and Jian (2014); Luong and Ha (2011); Michael (2011). Identification of significant fund characteristics offer valuable insights to investors as it will allow them to make prudent selection of mutual funds and make judicious investment decisions Babbar and Sehgal (2018). The worst-performing funds are in areas of the market that seem to offer ample opportunities for professional investors due to exacerbated mispricing Gupta-Mukherjee (2014). Expense and portfolio turnover ratios do not play a significant role, and them identification of significant fund characteristics offer valuable insights to investors as it will allow them to make prudent selection of mutual funds and make judicious investment decisions Babbar and Sehgal (2018). Indicate that investors derive utility from the socially responsible attribute, especially when returns are positive will be evidence that cash flows into socially responsible funds are more sensitive to lagged positive returns than cash flows into conventional funds, and weaker evidence that cash outflows from socially responsible funds are less sensitive to lagged negative returns. Based on this description, an evaluation research was carried out on the CSQI program which aims to obtain a series of recommendations to support the expansion of community implementation and participation in the CSQI program.

\section{MATERIALS AND METHODS}

This online survey research activity is part of the evaluation of the Regional Superior Product Development (RSPD) program for the first of the planned 3 (three) years. The activity has been going on for 6 (six) months from May to October 2020 with the partner of the activity, the Karya Trans Mandiri (KTM) Farmer Group, a compost producer for Superior Products for Rural Areas (Prukades) Dataran Kempas, Tebing Tinggi District, Tanjung Jabung Barat Regency, Jambi. The activities are carried out in stages with the scope of increasing the capacity of facilities and infrastructure for qurban cattle fattening, CSQI supply chain management training and good fattening practice of qurban cattle, as well as socialization of the CSQI program through brochure distribution and video viewing of the CSQI program and ongoing review of the CSQI program. on line. Evaluation of the program is focused on the attitudes and perceptions of potential potential participants in the CSQI program. The number of sources of information consisted of 87 people with the scope of the question items consisting of identification of potential participants, experiences in participating in the Qurban worship both as managers and participants, and responses to the CSQI program after a short video about qurban was presented. The data analysis method used descriptive analysis of the results of simple mathematical data processing (proportion), averaged and continued with multiple regression analysis with the probit 
model. Probit regression is a regression analysis used to describe the relationship between the dependent variable (response variable) usually symbolized by Y with the dichotomous (binary) measurement scale, and the independent variable (predictor variable) usually symbolized by $\mathrm{X}$, whose measurement scale is dichotomous, polycotomous or continuous Tinungki (2010). The equation model used in the evaluation of the CSQI program is as follows

where's

DECI $=$ Decision of prospective CSQI investors

$\alpha=$ Intercept

$\beta \mathrm{i}=$ The regression coefficient of the $\mathrm{i}^{\text {th }}$ variable

$\vartheta \mathrm{i}=$ The $\mathrm{i}^{\text {th }}$ dummy variable regression coefficient

PART $=$ Level of participation in qurban worship activities

EXPE $=$ Experience following qurban

PARP = Potential to CSQI qurban participant

$\mathrm{INFO}_{1}=$ Knowledge dummy variable " 1 for understanding and 0 others

$\mathrm{INFO}_{1}=$ Knowledge dummy variable " 1 for not understanding and 0 others

PLAN = Plan as qurban participant " 1 to participate and 0 to be uncertain"

$\mathrm{e}=$ Error term

Estimation of the equation model uses the EVIEW program with statistical tests jointly using the F-test and partially using the t-test.

\section{RESULTS AND DISCUSSIONS}

\subsection{BRIEF DESCRIPTION OF THE CQSI PROGRAM}

Cheap Qurban Sharia Investment (CSQI) is a sharia financing model developed to empower community funds in ensuring the availability of Qurban cattle at lower prices without having to reduce quality for Qurban participants and at the same time as an effort to empower fattening cattle households Novra et al. (2019). The implementation of sharia financing must fulfill two very important aspects, namely the syar'i aspect in the realization of financing that must be oriented towards Islamic sharia, and the economic aspect by considering the benefits for the institution and its customers Ilyas (2019). Sharia mutual funds can be one of the means in promoting financial inclusion program as it can be reached by all groups, especially small investors or retailers Asmara and Abubakar (2019). Furthermore, it is stated that the development of the financing concept of the CSQI model is expected to be able to minimize the occurrence of price speculation, reduce the trend of increasing beef cattle commodity prices from year to year (price stabilization) and provide investment certainty for smallholder livestock businesses and at the same time ensuring the quality and quantity of cattle for Qurban participants Novra and Suparjo (2020). Figure 1.

A financial intermediary is an entity that acts as the middleman between two parties in a financial transaction, such as a commercial bank, investment bank, mutual 


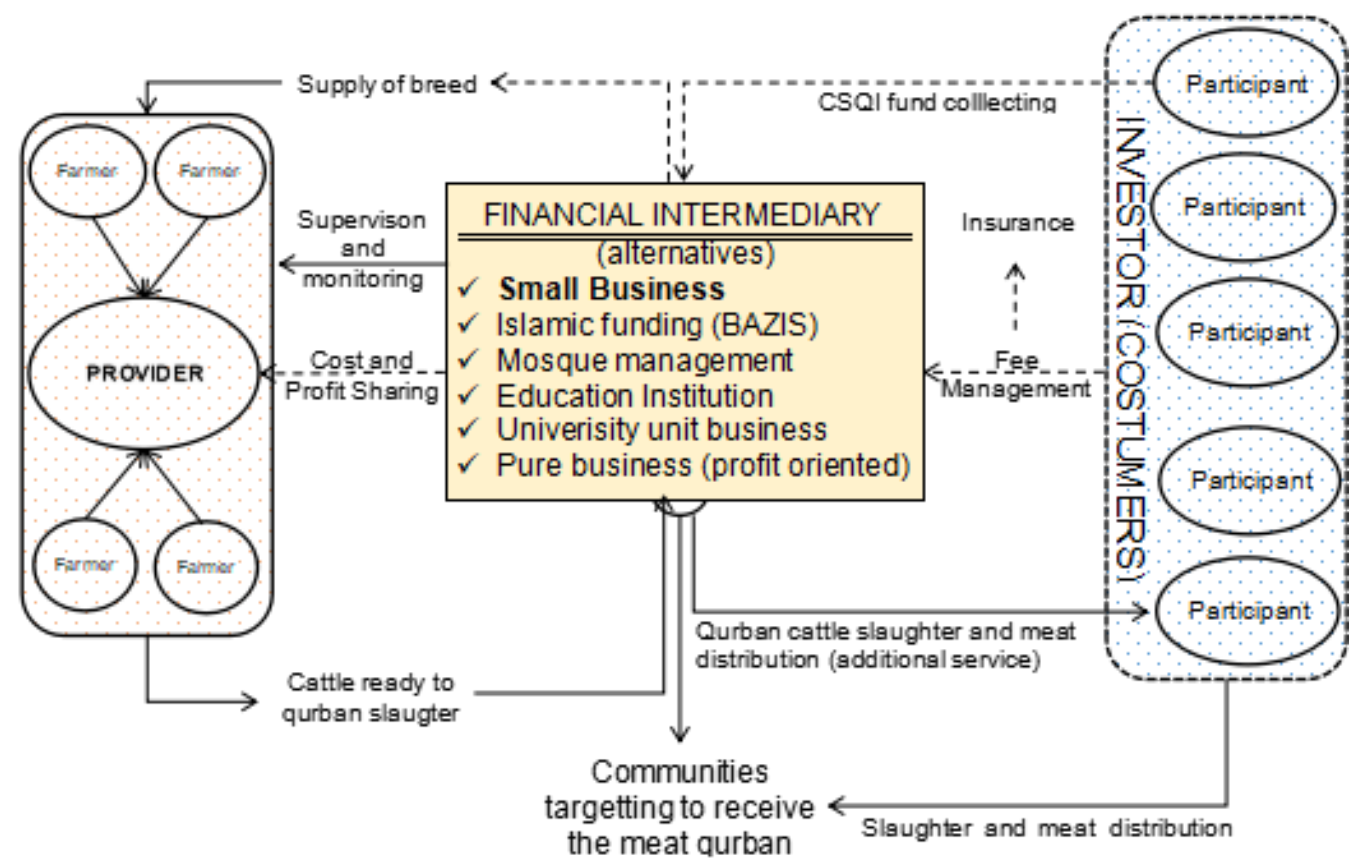

Figure 1. The Multiparties on CSQI model

Figure 1 TheMultiparties on CSQI Model

fund, or pension fund Chen (2020). The innovation management has a greater impact than the business partnership in improving the business performance of business units of the multiplay provider in Indonesia Purnomo et al. (2018). The CSQI management is in charge of financial intermediaries, namely companies or financial institutions that act as intermediaries between service providers and consumers Kahneman (2003). Financial intermediaries offer a number of benefits to the average consumer, including safety, liquidity, and economies of scale involved in banking and asset management Chen (2020). Mutual fund is an institution that pools money from many investors and invests the money in different securities, and a popular choice among investors because they offer features like professional management, diversification, affordability and liquidity.

Farmers as a provider, both individuals and groups, namely those responsible for raising feeder cattle supplied by intermediaries for the purpose of fattening qurban cattle. The compensation received by the first party is part of the results of the agreed profit-sharing system and the assistance and guidance program by the intermediary institutions. The community who has the right to receive meat from slaughtering qurban cattle can receive directly from intermediary institutions (managers) or directly from groups of qurban participants. Participants of qurban are fund owners (sharia investors) who entrust their qurban funds to be managed by intermediaries through a profit-sharing system. Compensation for their investment is the right to get qurban animals that meet the requirements in accordance with Islamic sharia. Qurban 
participants have 2 alternatives in the distribution of qurban meat, namely a) submitting it in full to the management institution or doing it themselves, including cutting, especially those of a group nature.

Individuals tend to have slow reaction in response to a loss, but tend to be reactive in response profits, and tend to think narrowly for a one-time investment, and broad thinking for the investment that has been done many times Kahneman (2003). The optimization of sharia mutual funds can be done by utilizing advanced technology in which one of them is the implementation of sharia mutual fund investments through the marketplace. Sharia mutual fund investment in the marketplace has the potential to develop as it can be done easily, quickly, and cheaply Ilyas (2019) The method of calculating qurban funds with an investment partnership of public funds, the profitsharing system uses an approach or calculation basis based on the value added (value added) of beef cattle fattening business. The stages in calculating the amount of lowcost qurban program contributions and the level of efficiency in the use of public funds are presented in Table 1.

\subsection{CSQI PROGRAM IMPLEMENTATION}

The existence of farmer groups that act as managers of intermediation institutions plays a role in connecting beef cattle breeder households with community groups that need cattle ready for slaughter for Qurban worship. This intermediation role can be developed using the concept of sharia financing combined with feedlot management (fattening). The advantage of the CSQI concept is the existence of time management that can optimize the distribution of maximum profit in a fair manner for the parties involved, namely farmers, poktan as managers and qurban participants. The qurban that takes place in the month of Dzulhijah (Figure 2 ) with a maximum length of 6 months for fattening.

Using the hijriyah calendar, the stages in the CSQI program are divided into 3 (three) stages as follows:

1. The stages of qurban participant registration starting after the previous year's qurban service, starting from 15 Dzulhijjah until entering the month of Muharram the following year.

2. The stages of collecting qurban funds (starting from the month of Muharram to Jumadil Akhir or a maximum of 5 months) from qurban participants in order to procure feeder cattle supplies and other costs which detail the components and costs will be explained in the calculation method. At this stage of fundraising, the procurement process will be carried out with the consideration that when the deduction on the day of Eid al-Adha has reached a minimum age of 2 years. The timing of buying feed for feeder cattle takes into account the conditions of qurban participant funds collected and the market price of feeder cattle at the time of purchase. Procurement of feeder cows must meet the requirements as livestock. The most important according to their characteristics are animals 
Table 1 Mechanisms and Stages of Determining the Amount of Fund for the SCQI Program and the Achievement of Program Efficiency.

\begin{tabular}{|c|c|c|c|c|}
\hline No & Variables & Symbol & Formula & Score \\
\hline 1 & $\begin{array}{l}\text { Price of Qurban Cows } \\
\text { (IDR/head) }\end{array}$ & $\mathrm{Pj}$ & A & 15.050 .000 \\
\hline 2 & $\begin{array}{l}\text { Price of breeding } \\
\text { (IDR/head) }\end{array}$ & $\mathrm{Pq}$ & B & 8.100 .000 \\
\hline 3 & $\begin{array}{c}\text { Operating cost (6 } \\
\text { months) ((IDR/head) }\end{array}$ & $\mathrm{C}$ & $\mathrm{C}$ & 2.085 .000 \\
\hline \multirow[t]{4}{*}{4} & Shared profit of CSQI (\%) & & & \\
\hline & a. Rambling farmer & sPp & $\mathrm{D}$ & 50,00 \\
\hline & $\begin{array}{l}\text { b. Qurban participant } \\
\text { (investor) }\end{array}$ & $\mathrm{sPq}$ & $\mathrm{E}$ & 35,00 \\
\hline & $\begin{array}{l}\text { c. Intermediaart Agency } \\
\text { Fee }\end{array}$ & $\mathrm{Fm}$ & $\mathrm{F}$ & 15,00 \\
\hline \multirow[t]{3}{*}{5} & Share Cost & & & \\
\hline & a. Rambling farmer (\%) & $\mathrm{sPp}$ & G & 35,00 \\
\hline & $\begin{array}{l}\text { b. Qurban participant } \\
\text { /investor (\%) }\end{array}$ & $\mathrm{sPq}$ & $\mathrm{H}$ & 50,00 \\
\hline 6 & $\begin{array}{l}\text { Value Added of fattening } \\
\text { (IDR) }\end{array}$ & VAU & $\mathrm{I}=\mathrm{A}-\mathrm{B}$ & 6.950 .000 \\
\hline 7 & Net Value added & NVAT & $\mathrm{J}=\mathrm{I}-\mathrm{C}$ & 4.865 .000 \\
\hline \multirow[t]{4}{*}{8} & $\begin{array}{l}\text { Gross value of share } \\
\text { cropping (IDR) }\end{array}$ & & & \\
\hline & a. Rambling farmer & $\mathrm{pP}$ & $\mathrm{K}=\mathrm{D} \times \mathrm{J}$ & 2.432 .500 \\
\hline & $\begin{array}{l}\text { b. Qurban participant } \\
\text { /investor }\end{array}$ & $\mathrm{pQ}$ & $\mathrm{L}=\mathrm{E} \times \mathrm{J}$ & 1.702 .750 \\
\hline & c. Fee management & Fee & $\mathrm{M}=\mathrm{Fx} \mathrm{J}$ & 729.750 \\
\hline \multirow[t]{3}{*}{9} & $\begin{array}{l}\text { Net value of share } \\
\text { cropping (IDR) }\end{array}$ & & & \\
\hline & a. Rambling farmer & NetP & $N=\underset{C}{\mathrm{~N}}-(\mathrm{Gx}$ & 1.702 .750 \\
\hline & $\begin{array}{l}\text { b. Qurban participant } \\
\text { /investor }\end{array}$ & NetQ & $\begin{array}{c}\mathrm{O}=\mathrm{L}-(\mathrm{Hx} \\
\mathrm{C})\end{array}$ & 660.250 \\
\hline \multirow[t]{4}{*}{10} & Magnitude of qurban & & & \\
\hline & a. Per heads & dQT & $\begin{array}{c}\mathrm{P}= \\
\mathrm{B}+\mathrm{K}+\mathrm{M}+\mathrm{Ins}\end{array}$ & 12.072 .250 \\
\hline & b. Per participant & dQP & $\mathrm{Q}=\mathrm{P} / 7$ & 1.724 .607 \\
\hline & c. Non-model & $\mathrm{dQPk}$ & $\mathrm{R}=\mathrm{A} / 7$ & 2.150 .000 \\
\hline \multirow[t]{4}{*}{11} & Efficiency & & & \\
\hline & a. Per heads & sQE & $S=A-P$ & 2.977 .750 \\
\hline & b. Per participant & $s Q P$ & $\mathrm{~T}=\mathrm{R}-\mathrm{Q}$ & 425.393 \\
\hline & c. Rate of efficency (\%) & eff & $\begin{array}{c}\mathrm{U}=(\mathrm{T}- \\
\mathrm{R} / \mathrm{R}) \times 100 \%\end{array}$ & 19,79 \\
\hline
\end{tabular}

Note: Sources (Novra, 2019). Ins = insurance (IDR 200.000/head) 


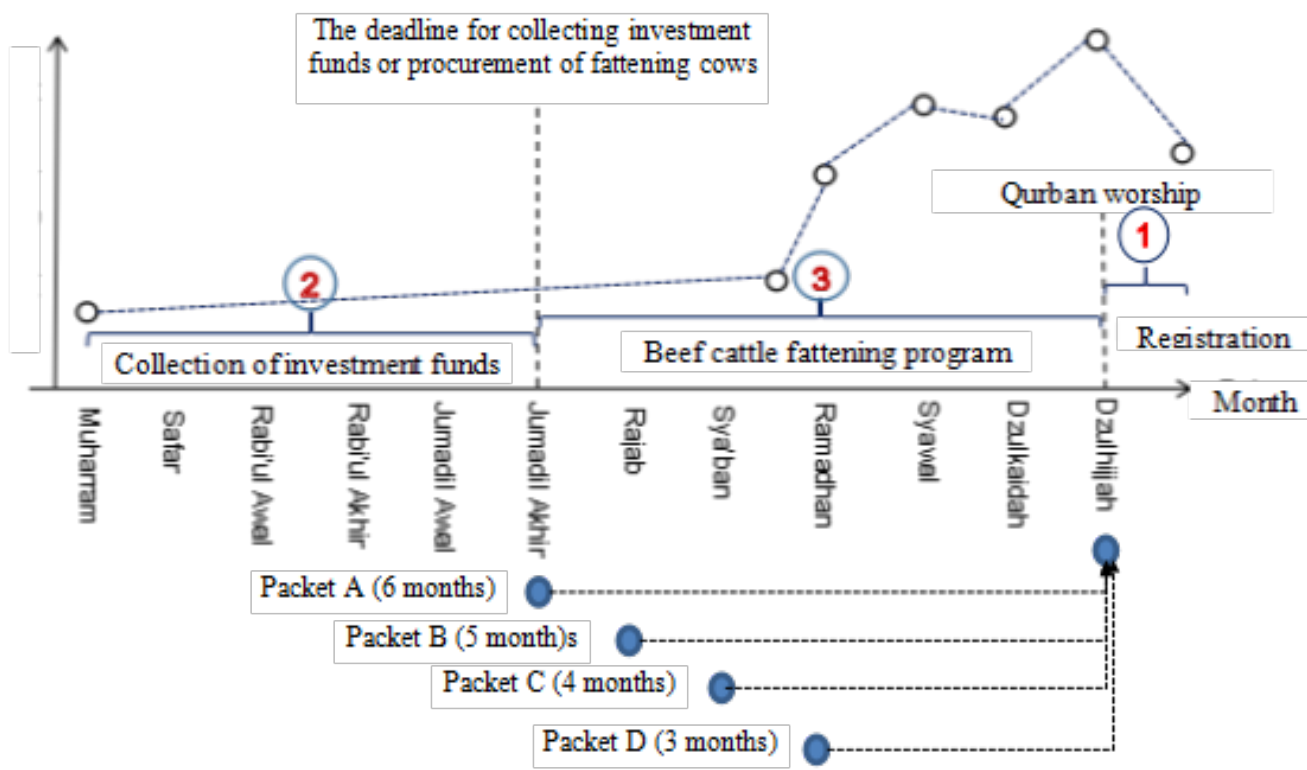

Figure 2 The stages and types of packages offered in the CSQI Program

that fulfill perfect and good characteristics with characteristics such as fat, lots of meat, perfect physical shape, good shape and expensive (Abdullah, 2005). Whereas what is interpreted from animals qurban is that their ears and tail are broken or their ears are torn, elongated or widened, their buttocks and udder are broken or part of both, such as severed nipples, crazy, loss of teeth (toothless) and no horns and broken horns.

3. The stages of raising feeder cattle (fattening) for 6 (six) months or more (Jumadil Akhir to 10 Dzulhijjah) depend on the time of purchase of feeder cattle.

The CSQI program also provides several alternative options for potential investors which will have implications for the deadline for repayment and the amount of investment, but the Qurban Cow that will be received will still be of the same quality and time. Alternative options for service services for the CSQI program are presented in Table 2.

\subsection{PROMOTION AND MARKETING OF CSQI PROGRAM SERVICES}

Socialization or more precisely advertising is a means of communication with users of a product or service in the form of a message conveyed by the sender which is intended to inform or influence the person receiving it The Economic Times, 2020. Definiton of "Advertising" ETPrime. Available (2020) Currently, advertising uses every possible medium to convey its message, such as through television, print media (newspapers, magazines, journals, etc.), radio, press, internet, direct sales, letters, contests, sponsorships, posters, clothing, events, colors, sound, visuals, and even 
Table 2 Service options, deadline for repayment, the amount of investment funds in the CSQI program

\begin{tabular}{|c|c|c|c|c|c|}
\hline \multirow[t]{2}{*}{ No } & \multirow[t]{2}{*}{$\begin{array}{l}\text { Service } \\
\text { Option }\end{array}$} & \multirow[t]{2}{*}{$\begin{array}{c}\text { Fattening } \\
\text { duration }\end{array}$} & \multirow[t]{2}{*}{$\begin{array}{l}\text { Repayment } \\
\text { deadline }\end{array}$} & \multicolumn{2}{|c|}{$\begin{array}{l}\text { Amount of investmen } \\
\text { (IDR) }\end{array}$} \\
\hline & & & & per-head & per-unit \\
\hline 1 & Type A & 6 months & Jumadil Akhir & $13,045,250$ & $1,863,607$ \\
\hline 2 & Type B & 5 months & Rajab & $13,531,750$ & $1,933,107$ \\
\hline 3 & Type C & 4 months & Syaban & $14,018,250$ & $2,002,607$ \\
\hline 4 & Type D & 3 months & Ramadhan & $14,504,750$ & $2,072,107$ \\
\hline
\end{tabular}

Note: Participants for each cow are 7 people

people (support). The marketing of CSQI program services does not use a direct approach in the form of mass gathering or in-person meetings because of the COVID19 pandemic case. The use of online media and brochures is the focus of the CSQI program's advertising using the following approaches:

1. Distribution of CSQI brochures explaining the program, program benefits and objectives, advantages and mechanisms and registration forms in offices, Muslim fashion shops, mosques and public places (public facilities). One of the important information conveyed in the brochure is the support of cultivation technology in the form of good practices in fattening beef cattle or Good Fattening Practice (GFP) based on oil palm frond waste in an integrated waste management (IWM) framework which consists of midrib processing. palm oil for fattening cattle feed, stable waste processing technology for the production of Trychokompos Insitu (TCI) and liquid waste for the production of Biourine A Plus. In situ trychokompos is a mixture of solid waste from cow pen and plant residues including legumes and dry grass which is processed into compost using the biological agent trychoderma decomposer. The TCI production process can be grouped into 3 (three) stages, namely preparation of raw materials (collection and drying), composting and post-composting, namely harvesting and packaging Novra and Suparjo (2020). Biourine plus is biourine that has been added by several biopharmaceutical plants (empon-empon). Besides being able to increase production, "biourine plus" is able to prevent diseases that attack plants, because of the added empon-empon. Hereinafter referred to as Biourine A Plus ( $\mathrm{A}=$ aeration) because in the production process using simple aeration techniques to remove (reduce) strong odors and a clearer and brighter color of bio-urine.

2. The use of social media such as YouTube and Facebook to introduce CSQI service products both about the CSQI program itself and the structuring and technology support programs used in the qurban cattle fattening program.

3. We also carry out socialization in the form of online discussions (case reviews) with an open registration 
Participants in the discussion in case review are potential candidates for CSQI program participants who come from academia, bureaucracy and the business world as well as the general public with relatively balanced sec-ratio between men and women (Table 3 ).

\begin{tabular}{|c|c|c|c|}
\hline \multicolumn{4}{|c|}{ Information sources characteristics } \\
\hline Jenis Kelamin & Proporsi (\%) & Latar Belakang Organisasi & Proporsi (\%) \\
\hline \multirow[t]{3}{*}{ a. Man } & & a. Livestock academics & 29.89 \\
\hline & & b. Non-livestock academics & 43.68 \\
\hline & & c. Moeslim academics & 6.90 \\
\hline \multirow[t]{3}{*}{ b. Male } & & d. Bureaucracy & 5.75 \\
\hline & & e. Businessman & 3.45 \\
\hline & & f. General public & 10.34 \\
\hline
\end{tabular}

Sources: Data processing (2020)

Academics are grouped into groups who know the technical aspects of animal husbandry, master religious and other issues from various fields of science. The proportion of these three groups of academics reaches more than $80 \%$ and comes from various universities, both public and private. Other groups come from outside of tertiary institutions both from the bureaucracy and the business world and the general public. The majority of participants expressed their interest in the CSQI program offered but not all immediately decided to participate as program participants (Figure 3 ). Proprosies who decide to join the CSQI program and those who are interested but have not decided to participate because information about the CSQI program is not clearly understood.

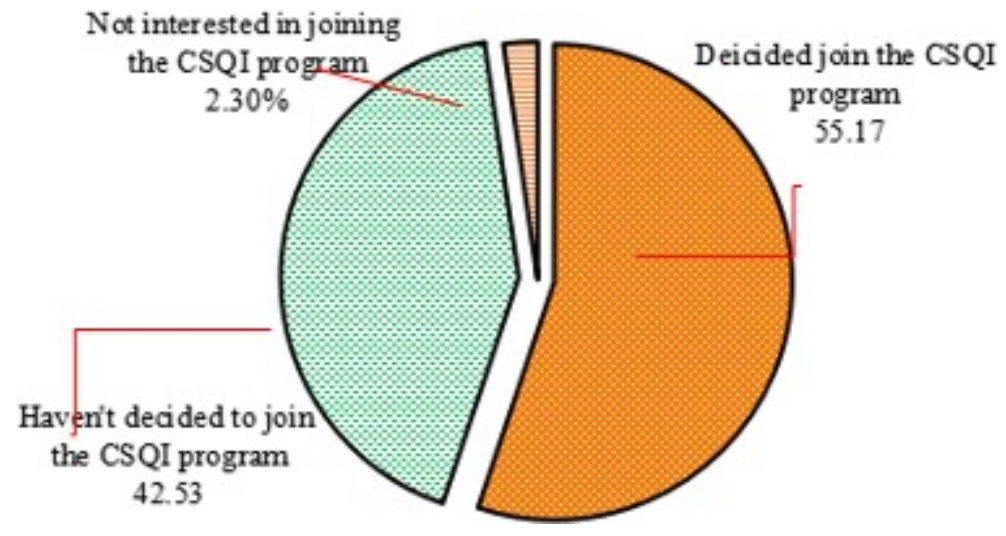

Figure 3 Decisions of prospective CSQI program participants 


\subsection{DETERMINING FACTORS FOR THE DECISION OF POTENTIAL INVESTORS IN THE CSQI PROGRAM}

The internal factors that influence the participant's decision to join the CSQI program can be explained from the estimation results of the probit equation model. The estimation results indicate that jointly the decision to participate in or participate in the CSQI program is determined by the experience of participation (committee and paticipant), the potential for participation and understanding of CSQI program information and plans for participation in the next year (Table 4).

Table 4 The estimation results of theprobit multiple regression equation.

\begin{tabular}{|c|c|c|c|c|}
\hline No & Variables & Coefficent & t-sig & Prob. \\
\hline 1 & Constant & 0.2793 & 1.5149 & 0.1337 \\
\hline 2 & $\begin{array}{l}\text { Participate } \\
\text { experiences }\end{array}$ & 0.0314 & 0.4158 & 0.6786 \\
\hline 3 & $\begin{array}{l}\text { Participant } \\
\text { experiences }\end{array}$ & 0.0116 & 0.2095 & 0.8346 \\
\hline 4 & $\begin{array}{l}\text { Potensi ikut } \\
\text { program CSQI }\end{array}$ & -0.0544 & -1.8889 & 0.0625 \\
\hline 5 & $\begin{array}{c}\text { Memahami } \\
\text { informasi CSQI }\end{array}$ & 0.3183 & 2.0134 & 0.0474 \\
\hline 6 & $\begin{array}{c}\text { Kurang } \\
\text { memahami } \\
\text { CSQI }\end{array}$ & 0.3293 & 2.8198 & 0.0061 \\
\hline 7 & $\begin{array}{c}\text { Memiliki } \\
\text { rencana ikut } \\
\text { qurban }\end{array}$ & 0.3102 & 2.4423 & 0.0168 \\
\hline \multicolumn{2}{|c|}{ Coeff. determinant } & 0.2059 & & \\
\hline \multicolumn{2}{|c|}{ F-sig } & 3.4569 & & \\
\hline \multicolumn{2}{|c|}{ Probabilty F } & 0.0043 & & \\
\hline
\end{tabular}

Sources: Estimation results of the EVIEW program

On the other hand, the magnitude of the influence of all factors on the decision to join the CSQI program is still relatively low and is more dominated by other factors, namely around $79.41 \%$. The estimation results indicate that jointly the decision to participate in or participate in the CSQI program is determined by the experience of participation (involvement) and being a qurban participant, the potential for participation in and understanding of CSQI program information and plans for participation in the next year. On the other hand, the magnitude of the influence of all factors on the decision to join the CSQI program is still relatively low and is more dominated by other factors, namely around $79.41 \%$. Partially, the experience factor and the level of participation do not have a significant influence on the decision of potential participants to decide on their participation in the CSQI program. However, the higher the level of participation and experience in qurban activities will increase their chances of participating and investing in the CSQI program. The majority of experiences with participation levels are quite high as shown in Figure 4. 


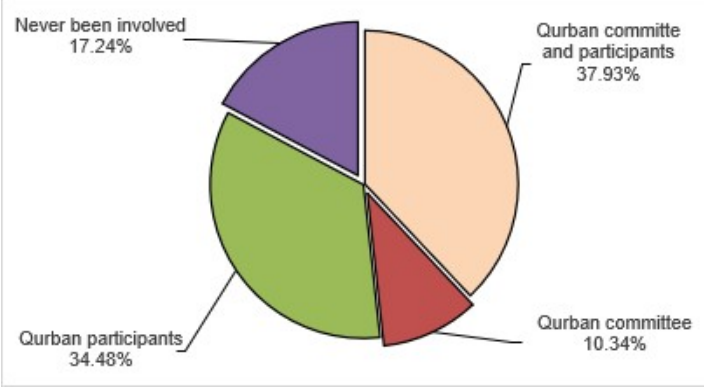

Figure 4 Participation Experience in Management of Qurban Worship

The majority of participants have experience in managing qurban both as a committee and only as qurban participants and some even only participate as qurban committee. This kind of phenomenon is quite increasing because usually the qurban committee members are qurban participants and this usually occurs in young people who do not have the ability to set aside some of their sustenance to pay for qurban but are trusted to be managers. On the other hand, those who only have experience as qurban participants are usually not members of qurban groups but entrust their funds to the closest qurban organizing groups such as offices, "majelis taklim" and neighborhood group. Based on the proportion of participatory experiences, it is indicated that most of the prospective CSQI program participants already have experience as qurban participants but have different experiences as shown in Figure 5 .

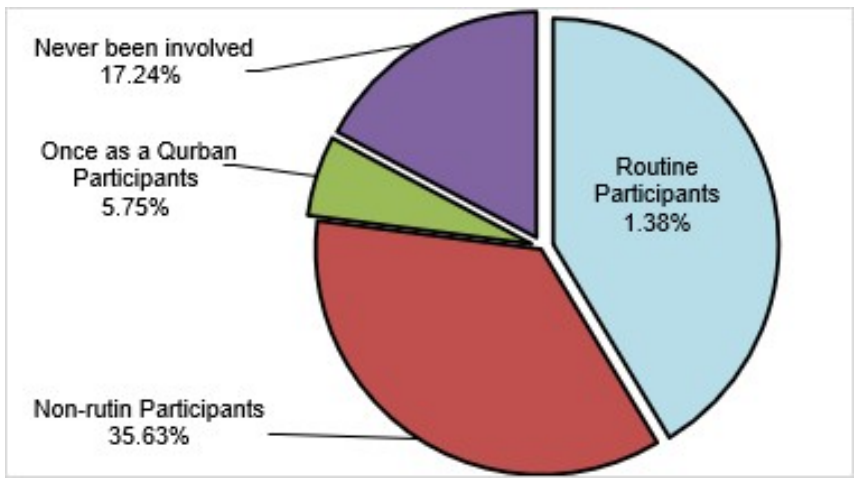

Figure 5 Experiences as a Qurban Participants

The effect of these two experience variables on the opportunity to become a participant in the CSQI program provides a positive indication that all members of the community, both as committee members, participants and those who have not experienced the same potential. To find out which group is the priority target, it can be seen from the variables that significantly affect the opportunities to become CSQI participants, namely potential participants, information and level of understanding 
received and plans that have been decided in the following year. The level of potential participants is determined based on the qurban financing system which is carried out both in cash (in full) and through qurban fund "arisan" with the composition as shown in Figure 6.

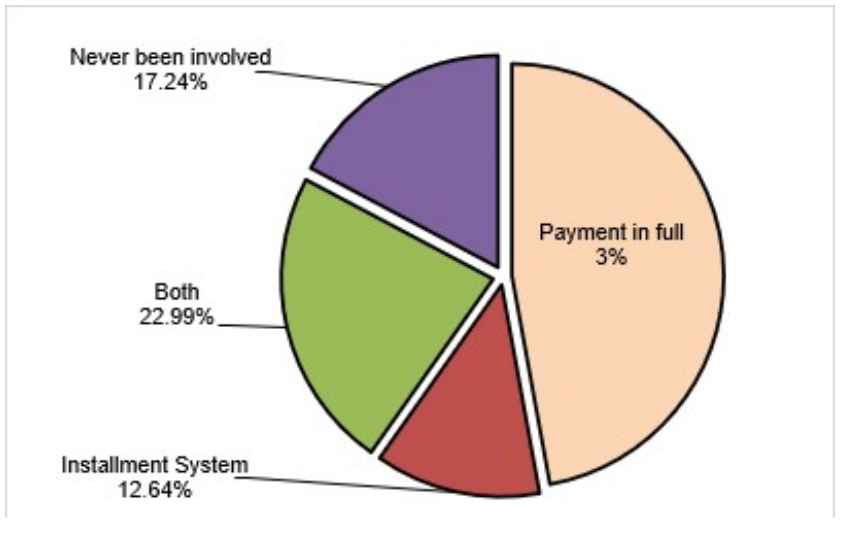

Figure 6 CSQI Fund Payment Mechanism

Initial assumptions that the most potential group were those who made payments in full in full than those who went through arisan turned out to be based on the results of the estimation. This can be seen from the significant influence of potential participants with the direction of negative influence on the opportunity to become a participant in CSQI. The higher the potential participant, which means the group that makes payments directly (in full), the lower the opportunity to participate in becoming a participant in the CSQI program. This means that in the promotion and marketing of CSQI service products it will be more effectively directed by the arisan system than with one-time payments. The development of a model or mechanism for the payment of the installment system needs to be developed so that it is not too burdensome for prospective CSQI program participants. Promotion to management institutions as shown in Figure 7 can be a choice of targets for promotional activities for the CSQI program.

The qurban management institutions that are often used by the community in the mobilization of qurban funds are religious groups such as majelis taklim and yasinan, followed by local arisa at the RT (neighborhood unit) and office levels. Promotion and socialization of the CSQI program is very important because the estimation results also indicate that the opportunity to become a program participant differs significantly between understanding groups from the information received by potential CSQI participants. Another factor that significantly affects the opportunity to become a participant in the CSQI program is the level of readiness of the candidates to carry out qurban in the next period. This is reflected in the significant difference between groups that already have plans and those who have not decided to become qurban participants in the coming period. 


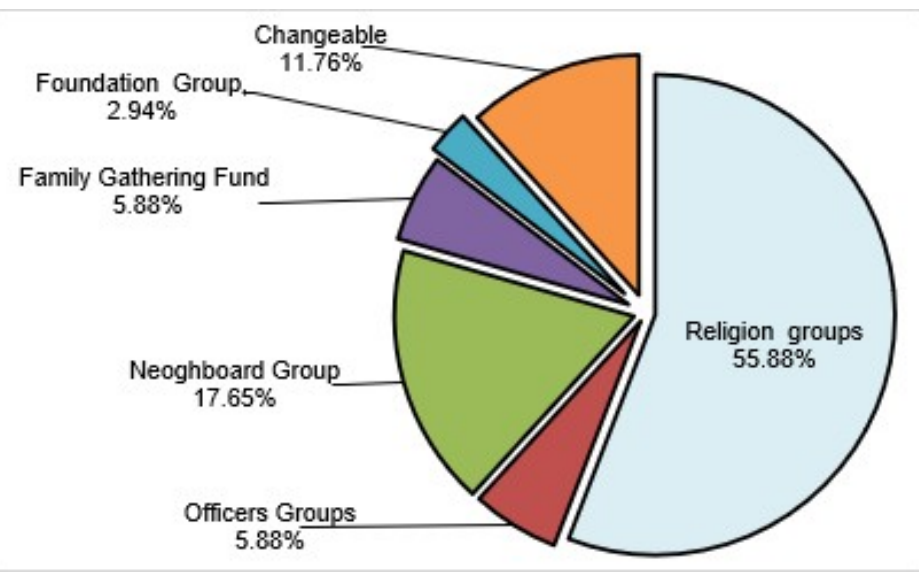

Figure 7 Options for Qurban Fund Management Institutions for Prospective CSQI Program Participants

\section{CONCLUSIONS AND RECOMMENDATIONS}

\subsection{CONCLUSION}

Based on the results of the evaluation of the CSQI program that has been introduced to potential potential participants who participate in the CSQI program activities, some conclusions can be drawn as follows:

1. The results of the evaluation of potential qurban pesesrta candidates show that generally the sources of information come from academics, practitioners and the bureaucracy are interested $(56.17 \%)$ to participate in the CSQI program while the situation has not decided (42.52\%) and is not interested at all (2.29\%),

2. The high proportion that has not yet decided is estimated because the majority of potential CSQI program participants have low information, namely $29.64 \%$ who already know but do not understand, while $57.47 \%$ still have never received information even though they have watched a video about the CSQI program.

3. A person's experience both in participating in the management of qurban activities and as a participant does not have a significant effect on their decision to join the CSQI program.

4. A person's decision to participate in the CSQI program is determined by the payment system, the information they receive and the level of their readiness to face qurban activities in the next period.

\subsection{POLICY RECOMMENDATIONS}

The promotion and marketing policies of the CSQI program need to be improved or modified in order to provide clear information and provide an alternativearisan 
(installment) repayment system and so that it is effectively focused on the target market segment in the form of religious-related qurban management institutions, offices and neighborhoods.

\section{ACKNOWLEDGEMENTS}

The Regional Superior Product Strengthening Program is funded by the Directorate of Research and Community Service, Ministry of Education and Culture of the Republic of Indonesia with contract number 1754/UN21.18.AM.SPK/2020 dated May $27^{\text {th }}$, 2020. Thank you also to the Karya Trans Mandiri farmer group, Dataran Kempas Village, Tebing Tinggi District, West Tanjung Jabung Regency, Jambi, Indonesia.

\section{REFERENCES}

Abdul-Rahman, A., Latif, R. A., Muda, R., \& Abdullah, M. A. (2014). Failure and potential of profit-loss sharing contracts: A perspective of New Institutional, Economic (NIE) Theory. Pacific-Basin Finance Journal, 28, 136-151. Retrieved from https://dx.doi.org/ 10.1016/j.pacfin.2014.01.004 10.1016/j.pacfin.2014.01.004

Ashari, S. (2005). Prospects of Sharia Financing for the Agricultural Sector. Agro-Economic Research Forum, Center for Agricultural Economics and Policy Studies, 23(2), 132-137. Asmara, T.T.P., \& Abubakar, L. (2019). The Optimization of Sharia Mutual Fund as an Investment Means to Promote Financial Inclusion in Indonesia. UNIFIKASI : Jurnal Ilmu Hukum, 6(2), 126-126. Retrieved from https://dx.doi.org/10.25134/unifikasi .v6i2.1849 10.25134/unifikasi.v6i2.1849

Babbar, S., \& Sehgal, S. (2018). Mutual Fund Characteristics and Investment Performance in India. Management and Labour Studies, 43(1-2), 1-30. Retrieved from https://dx.doi .org/10.1177/0258042x17745183 10.1177/0258042x17745183

Basuki, N., \& Khoiruddin, M. (2018). Comparative Performance Islamic Shares Mutual Funds Between Indonesia And Malaysia. Ekuilibrium : Jurnal Ilmiah Bidang Ilmu Ekonomi, 13(1), 26-26. Retrieved from https://dx.doi.org/10.24269/ekuilibrium.v13i1.918 10 .24269/ekuilibrium.v13i1.918

Boo, Y. L., Ee, M. S., Li, B., \& Rashid, M. (2017). Islamic or conventional mutual funds: Who has the upper hand? Evidence from Malaysia. Pacific-Basin Finance Journal, 42, 183-192. Retrieved from https://dx.doi.org/10.1016/j.pacfin.2016.01.004 10.1016/ j.pacfin.2016.01.004

Chen, J. (2020). Financial Intermediary: Investopedia: Corporate finance. Financial Intermediary: Investopedia: Corporate finance. Retrieved from https://www.investopedia .com/terms/f/financialintermediary.aspSeptember23th

Codification of Bank Indonesia regulations - liabilities and capital for the implementation of sharia principles in the activities of raising and channeling funds as well as sharia services, sharia bank products and sharia business units. (2012). Jakarta.

Cuong, P. K., \& Jian, Z. (2014). Factors Influencing Individual Investors' Behavior: An Empirical Study of the Vietnamese Stock Market. American Journal of Business and Management, 3(2). Retrieved from https://dx.doi.org/10.11634/216796061403527 10 $.11634 / 216796061403527$ 
The Economic Times, 2020. Definiton of "Advertising" ETPrime. Available. (2020). The Economic Times, 2020. Definiton of "Advertising" ETPrime. Retrieved from https:// economictimes.indiatimes.com/definition/advertising

Firman, A., Sulaeman, L., Herlina, M., \& Sulistyati. (2018). Analysis of Balance Supply and Demand of Cattle and Beef Cattle in West Java. MIMBAR AGRIBISNIS Journal of Agribusiness Insight Scientific Society Thought, 4(2), 98-108.

Gupta-Mukherjee, S. (2014). Investing in the "New Economy": Mutual Fund Performance and the Nature of the Firm. Journal of Financial and Quantitative Analysis, 49(1),165-191. Retrieved from https://dx.doi.org/10.1017/s0022109014000179 10 $.1017 / \mathrm{s} 0022109014000179$

Halim, A. (2005). Analisis investasi. second edition. salemba 4 publishing..

Hervé, F., Manthé, E., Sannajust, A., \& Schwienbacher, A. (2019). Determinants of individual investment decisions in investment-based crowdfunding. Journal of Business Finance \& Accounting, 46(5-6), 762-783. Retrieved from https://dx.doi.org/10.1111/jbfa.12372 10.1111/jbfa.12372

Hoepner, A. G., Rammal, H. G., \& Rezec, M. (2011). Islamic mutual funds' financial performance and international investment style: evidence from 20 countries. The European Journal of Finance, 17(9-10), 829-850. Retrieved from https://dx.doi.org/10.1080/1351847x .2010.538521 10.1080/1351847x.2010.538521

Ilham, N. (2001). Analysis of Supply and Demand for Beef in Indonesia. National Seminar on Animal and Veterinary Technology Papers.

Ilyas, R. (2019). The Concept of financing in Islamic banking. Kudus Islamic University Research Journal, 9(1), 183-204.

Jagongo, A., \& Mutswenje, V.S. (2014). A Survey of the Factors Influencing Investment Decisions: The Case of Individual Investors at the NSE. International Journal ofHumanities and Social Science, 4(4), 92-102.

Kahneman, D. (2003). The Psychology of Risky Choices"Address before the Investment Company Institute. Washington DC.

Kammer, A., Norat, Piñón, A., Prasad, C., Towe, Z., \& Zeidane. (2015). Opportunities, Challenges, and Policy Options. IMF (International Moneter Fund) Discussion Note. Islamic Finance: Opportunities, Challenges, and Policy Options. IMF (International Moneter Fund) Discussion Note. Retrieved from https://www.imf.org/external/pubs/ft/sdn/ 2015/sdn1505.pdf

Kariasa, K. (2012). Analysis of Beef Supply and Demand in Indonesia Before and During the Economic Crisis: An Analysis of 2005 Beef Self-Sufficiency Projection. Analysis of Beef Supply and Demand in Indonesia Before and During the Economic Crisis: An Analysis of 2005 Beef Self-Sufficiency Projection. Retrieved from https://www.neliti.com/publications/43906/analisis-penawaran-dan-permintaan -daging-sapi-di-indonesia-sebelum-dan-saat-kris

Lubis, A. N., Isfenti, A. F., Khaira, M., \& Juli. (2013). Perilaku investor keuangan. USU Press.

Luong, L. P., \& Ha, D. (2011). Behavioral Factors Influencing Individual Investors' Decision Making and Performance. Thesis. Retrieved from opeconomica. files.word-press.com. Umea School of Business (Unpublished doctoral dissertation).

Mahmud, S. (2002). Making rights real in Bangladesh through collective citizen action. IDS Bulletin, 33(2), 1i-12. Retrieved from https://dx.doi.org/10.1111/j.1759-5436.2002 .tb00026.x 10.1111/j.1759-5436.2002.tb00026.x

Meinzen-Dick, R., \& Knox, A. (1999). Collective action, property rights and devolution of natural resource management: a conceptual paper. Paper to international workshop 
on collective action, property rights and devolution of natural resource management: Exchange of knowledge and implication for policy. Puerto Azul, 21-25.

Michael, L. M. (2011). An Examination of the Determinants of Top Management Support of Information Technology Projects. Doctor of Philosophy, Stevens Institute of Technology. An Examination of the Determinants of Top Management Support of Information Technology Projects. Doctor of Philosophy.

Murniati, W. (2018). Additional Number of Investment to the Simulation of Profit Calculation of Syariah Musyarakah Investment Model.Journal of Mathematics Education, 3(2), 223239.

Novra, A. (2020). Ummah Empowermenr, and Beef Cattle Commodity Price Stabilization, National Seminar Proceeding Indonesian Moeslim Lecturer "Revitalisasi Peran Akademisi Bagi Peningkatan Kualitas. Cheap Qurban Sharia Investment Model, 1, 1933.

Novra, A., Adriani, Suparjo, Nelson, S., \& Novianti. (2019). Strengthening the business of farmer groups engaged in waste-based oil palm-cattle integration in Mestong District. Riau Journal of Empowerment, 2(2), 43-54.

Novra, A., Adriani, A., Depison, D., \& Octavia, A. (2020). Cheap Qurban Syariah Investment (CQSI) Program, Empowerment and Price Stabilization. Jurnal Ekonomi Pembangunan, 18(2), 103-103. Retrieved from https://dx.doi.org/10.22219/jep.v18i2.12434 10.22219/jep.v18i2.12434

Novra, A., \& Suparjo. (2020). Collective Action Model: Facing Temporary Loss Income while the Rubber Replanting Program. IOP Conference Series: Earth and Environmental Science, 518(1), 012059-012059. Retrieved from https://dx.doi.org/10.1088/1755 -1315/518/1/012059 10.1088/1755-1315/518/1/012059

Pahlevi, R. W., \& Oktaviani, I. I. (2018). Determinants of Individual Investor Behaviour in Stock Investment Decisions. AFRE (Accounting and Financial Review), 1(2), 53-61. Retrieved from https://dx.doi.org/10.26905/afr.v1i2.2427 10.26905/afr.v1i2.2427

Permata, R. (2014). Analysis of the Influence of Mudharabah and Musyarakah Financing on the Level of Profitability (Return on Equity) (Study on Sharia Commercial Banks Registered at Bank Indonesia Periode 2009-2012. Jurnal Administrasi Bisnis (JAB), 12(1), $1-9$.

Prawirasasra, K. P.(2016). Behavioral finance in investment decision-making process. In Proceedings of 66th The IIER International Conference (pp. 978-93).

Purnomo, D. S., Sucherly, Y. S., Suryana, D., \& Sari. (2018). The Effect of Business Partnership and Innovation Management to Business Performance of Business Units of Multiplay Provider in Indonesia. Academy of Strategic Management Journal, 17(2), 1-12.

Reily. (2018). Kemendag Terbitkan Izin Impor 36 Ribu Ton Daging Sapi. Kemendag Terbitkan Izin Impor 36 Ribu Ton Daging Sapi. Retrieved from https://katadata.co.id/ekarina/ berita/5e9a5603350ba/kemendag-terbitkan-izin-impor-36-ribu-ton-daging-sapi

Saptana, N., \& Ilham. (2017). Supply Chain Management of Cattle and Beef Commodities. Agricultural Policy Analysis Journal, 15(1), 83-98.

Sugema, I., Bakhtiar, T., Effendi, J., \& J. (2010). Interest versus profit-loss sharing credit contract: effciency and welfare implications. International Research Journal of Finance and Economics, 45(2), 58-67.

Syamsuddin, N., Komarudin, H. Y., \& Siagian. (2007). Are community aspirations being accommodated in development plans? A lesson from collective action in Jambi. CIFOR Governance Brief (34). 
Tinungki, G. M. (2010). Aplikasi Model Regresi Logit dan Probit pada Data Kategorik. Statistik dan Komputasi, 6(2), 107-114.

Widiati, R. (2012). Financial Feasibilty of Beef Cattle Breeding with Varios Capital Aids in Rural Area of Gunung Kidul District of Yogyakarta. Animal Bulletin, 36(2), 122-128. 